\title{
Sugar Esters from Globularia orientalis
}

\author{
İhsan Çalişa,*, Hasan Kirmizibekmez ${ }^{\mathrm{a}}$, Deniz Tasdemir ${ }^{\mathrm{a}}$, Otto Sticher ${ }^{\mathrm{b}}$ \\ and Chris M. Ireland ${ }^{\mathrm{c}}$ \\ a Department of Pharmacognosy, Faculty of Pharmacy, Hacettepe University, \\ TR-06100 Ankara, Turkey. Fax: 90-312-3114777. E-mail: icalis@hacettepe.edu.tr \\ b Department of Applied Biosciences, Institute of Pharmaceutical Sciences, \\ Swiss Federal Institute of Technology (ETH) Zurich, CH-8057 Zürich, Switzerland \\ c Department of Medicinal Chemistry, University of Utah, Salt Lake City, \\ Utah 84112, USA \\ * Author for correspondence and reprint requests \\ Z. Naturforsch. 57 c, 591-596 (2002); received March 12/April 14, 2002 \\ Globularia orientalis, Sugar Esters, Iridoid and Phenylethanoid Glycosides
}

From the methanolic extract of the underground parts of Globularia orientalis, a new antioxidant sugar ester was isolated. The structure of the new compound, globularitol (1), was identified as 6 - $O$-feruloyl- $\beta$-D-glucopyranosyl-( $(1 \rightarrow 6)$-glucitol by spectroscopic methods (1D and 2D NMR, ESI- and FAB-MS) and confirmed by chemical means.

\section{Introduction}

The genus Globularia (Globulariaceae) is represented by eight species in Turkish flora (Davis, 1982), some members of which (G. alypum, G. trichosantha) are well known in Anatolian folk medicine (Baytop, 1984; Sezik, 1991). As part of our continuing search for bioactive new natural products from Turkish Globularia species (Calis et al., 1999 and 2001), we investigated Globularia orientalis. Methanolic extracts of both aerial and the underground parts of this plant exhibited significant antioxidant effects, based on the scavenging activity of the stable 2,2-diphenyl-1-picrylhydrazyl (DPPH) free radical. Bioactivity-guided isolation of the underground parts afforded a new sugar ester, globularitol (1), along with the known sucrose esters 6 - $O$-caffeoyl- $\beta$-D-fructofuranosyl- $(2 \rightarrow 1)$ - $\alpha$ D-glucopyranoside (2) and 6- $O$-feruloyl- $\beta$-D-fructofuranosyl- $(2 \rightarrow 1)$ - $\alpha$-D-glucopyranoside (3), 10- $O$ benzoylcatalpol and geniposide. Activity-directed fractionation of the aerial parts, using the same antioxidant assay, furnished an acetophenone glycoside (picein), eight iridoid glycosides; asperuloside, alpinoside, aucubin, catalpol, geniposidic acid, 10-O-benzoylcatalpol, globularin, melampyroside and three phenylethanoid glycosides (calceolarioside A, verbascoside, leucosceptoside A). In this report, we describe isolation and structure elucidation of globularitol (1). The antioxidant activity of the isolates will also be presented.

\section{Material and Methods}

\section{General experimental procedures}

Optical rotations were measured on a Rudolph autopol IV Polarimeter using a sodium lamp operating at $589 \mathrm{~nm}$. UV spectra were recorded on a Shimadzu UV-160A spectrophotometer. IR spectra $(\mathrm{KBr})$ were measured on a Perkin Elmer 2000 FT-IR spectrometer. A Varian instrument (500 $\mathrm{MHz}$ for ${ }^{1} \mathrm{H}$ and $125 \mathrm{MHz}$ for ${ }^{13} \mathrm{C}$ ) with a Nalorac MDBG $3 \mathrm{~mm}$ probe was used to acquire NMR data. Negative and positive mode ESIMS were recorded on a Finnigan TSQ 7000 instrument. FABMS measurements were performed on a Finnigan MAT95 spectrometer. TLC analyses were carried on silica gel $60 \mathrm{~F}_{254}$ precoated plates (Merck, Darmstadt); detection by $1 \%$ vanillin/ $\mathrm{H}_{2} \mathrm{SO}_{4}$. For MPLC separations, a Lewa M5 pump, a LKB 17000 Minirac fraction collector, a Rheodyne injector, and a Büchi column (column dimensions $2.6 \times 46 \mathrm{~cm}$, and $1.8 \times 35 \mathrm{~cm})$ were used. Silica gel 60 (0.063-0.200 mm; Merck, Darmstadt) and polyamide (Woelm; Eschwege, Germany) were utilized for open CC. MPLC separations were performed over LiChroprep C-18 (Merck) 
material. Gentiobiose and isomaltitol were purchased from Merck and Fluka, respectively.

\section{Plant material}

Globularia orientalis L. was collected from Ankara, Bala, Turkey, in June 1998. A voucher specimen (HUEF 98008) has been deposited at the Herbarium of the Department of the Pharmacognosy, Faculty of Pharmacy, Hacettepe University, Ankara, Turkey.

\section{Extraction and isolation}

The air-dried aerial parts $(200 \mathrm{~g})$ of $G$. orientalis were extracted with $\mathrm{MeOH}(2 \times 900 \mathrm{ml})$ at $45^{\circ} \mathrm{C}$. The combined methanolic extracts were evaporated to dryness in vacuo ( $41 \mathrm{~g}$, yield $20.5 \%$ ). The crude extract was dissolved in $\mathrm{H}_{2} \mathrm{O}$ and partitioned against $\mathrm{CH}_{2} \mathrm{Cl}_{2}$. The freeze-dried $\mathrm{H}_{2} \mathrm{O}$ phase $(36.7 \mathrm{~g})$ was subjected ton vacuum liquid chromatography (VLC) over $\mathrm{Si}$ gel, using a $\mathrm{CH}_{2} \mathrm{Cl}_{2}-\mathrm{MeOH}-\mathrm{H}_{2} \mathrm{O}$ gradient system (90:10:1 to $60: 40: 4 \mathrm{v} / \mathrm{v} / \mathrm{v}$ ) to yield fractions $\mathrm{A}-\mathrm{H}$. Fraction C $(3.1 \mathrm{~g})$ was subjected to $\mathrm{C}_{18}$ medium pressure liquid chromatography $\left(\mathrm{C}_{18}\right.$-MPLC) using increasing amount of $\mathrm{MeOH}$ in $\mathrm{H}_{2} \mathrm{O}(30-60 \%)$ to afford picein $(10 \mathrm{mg})$, asperuloside (26 mg), 10- $O$-benzoylcatalpol $(672 \mathrm{mg})$, a mixture (1:1) of globularin and melampyroside (786 mg) and impure calceolarioside A (148 mg). The latter was further chromatographed by $\mathrm{Si}$ gel $\mathrm{CC}$ eluting with $\mathrm{CHCl}_{3}-$ $\mathrm{MeOH}-\mathrm{H}_{2} \mathrm{O}(90: 10: 1$ to $80: 20: 1 \mathrm{v} / \mathrm{v} / \mathrm{v})$ to yield $8 \mathrm{mg}$ of pure calceolarioside A. Fraction D (6.2 g) was similarly separated by $\mathrm{C}_{18}$-MPLC using 5 to $100 \% \mathrm{MeOH}$ in $\mathrm{H}_{2} \mathrm{O}$ as eluent to give catalpol $(197 \mathrm{mg})$, aucubin $(31 \mathrm{mg})$ and six additional fractions $\mathrm{D}_{3}-\mathrm{D}_{8}$. Fraction $\mathrm{D}_{3}(59 \mathrm{mg})$ was rechromatographed on silica $\mathrm{CC}\left(\mathrm{CHCl}_{3}-\mathrm{MeOH}-\mathrm{H}_{2} \mathrm{O}\right.$, $80: 20: 2$ to $70: 30: 3 \mathrm{v} / \mathrm{v} / \mathrm{v})$ to yield additional amounts of picein $(28 \mathrm{mg})$ and geniposidic acid $(11 \mathrm{mg})$. Fraction $\mathrm{D}_{5}(670 \mathrm{mg})$ was applied to a $\mathrm{Si}$ gel column eluting with $\mathrm{CHCl}_{3}-\mathrm{MeOH}-\mathrm{H}_{2} \mathrm{O}$ mixtures $(80: 20: 1$ to $61: 32: 7 \mathrm{v} / \mathrm{v} / \mathrm{v})$ and gave two fractions $\mathrm{D}_{5 \mathrm{a}}(89 \mathrm{mg})$ and $\mathrm{D}_{5 \mathrm{~b}}(300 \mathrm{mg})$. Fraction $\mathrm{D}_{5 \mathrm{~b}}$ was purified by $\mathrm{C}_{18}$-MPLC using $5 \%$ stepwise gradient elution from $10 \%$ to $45 \% \mathrm{MeOH}$ in $\mathrm{H}_{2} \mathrm{O}$ to obtain alpinoside $(42 \mathrm{mg})$, calceolarioside A (9 $\mathrm{mg}$ ) and verbascoside (67 $\mathrm{mg})$. Leucosceptoside A $(38 \mathrm{mg})$ was obtained by $\mathrm{Si}$ gel $\mathrm{CC}$ of fraction $\mathrm{D}_{7}(136 \mathrm{mg})$.
The air-dried underground parts (330 g) of G. orientalis were also extracted with $\mathrm{MeOH}$ $(2 \times 1500 \mathrm{ml})$ and filtered. The filtrate was concentrated to dryness in vacuo ( $24 \mathrm{~g}$, yield $7.3 \%)$. The extract was subjected to Polyamide $\mathrm{CC}$ eluting with a $10 \%$ stepwise gradient from $\mathrm{H}_{2} \mathrm{O}$ to $\mathrm{MeOH}$ to give fractions $\mathrm{A}-\mathrm{K}$. Fraction $\mathrm{C}(5.0 \mathrm{~g})$ was subjected to $\mathrm{C}_{18}$-MPLC employing $\mathrm{H}_{2} \mathrm{O}-\mathrm{MeOH}$ mixtures $(5-50 \% \mathrm{MeOH})$ and yielded eight fractions, $\mathrm{C}_{1}-\mathrm{C}_{8}$. Fraction $\mathrm{C}_{2}(161 \mathrm{mg})$ was rechromatographed over Si gel eluting with $\mathrm{CH}_{2} \mathrm{Cl}_{2}-\mathrm{MeOH}-$ $\mathrm{H}_{2} \mathrm{O}(70: 30: 3 \mathrm{v} / \mathrm{v} / \mathrm{v})$ to give $10-O$-benzoylcatalpol (43 mg). Fraction $\mathrm{C}_{4}(73 \mathrm{mg})$ was likewise applied to a $\mathrm{Si}$ gel column to afford 6- $O$-caffeoyl- $\beta$-D-fructofuranosyl-( $2 \rightarrow 1)$ - $\alpha$-D-glucopyranoside $(2,12 \mathrm{mg})$. Repeated chromatography of fraction $\mathrm{C}_{5}(340 \mathrm{mg})$ by $\mathrm{Si}$ gel $\mathrm{CC}$ employing the same mobile phase gave $\quad 6-O$-feruloyl- $\beta$-D-fructofuranosyl- $(2 \rightarrow 1)-\alpha$ D-glucopyranoside $(\mathbf{3}, 114 \mathrm{mg})$ and four additional fractions, $\mathrm{C}_{5 \mathrm{a}}-\mathrm{C}_{5 \mathrm{~d}}$. Fraction $\mathrm{C}_{5 \mathrm{a}}(23 \mathrm{mg})$ afforded geniposide $(9 \mathrm{mg})$ by $\mathrm{Si}$ gel $\mathrm{CC}\left(\mathrm{CH}_{2} \mathrm{Cl}_{2}-\mathrm{MeOH}-\right.$ $\mathrm{H}_{2} \mathrm{O}$, 90:10:1 v/v/v). Fr $\mathrm{C}_{5 \mathrm{~d}}(30 \mathrm{mg})$ was passed through a Silica column employing an isocratic $\mathrm{CHCl}_{3}-\mathrm{MeOH}-\mathrm{H}_{2} \mathrm{O}$ mixture (70:30:3 v/v/v) and afforded globularitol $(\mathbf{1}, 10 \mathrm{mg})$.

Globularitol (1): Amorphous yellowish solid; $[\alpha]_{\mathrm{D}}^{20}-22^{\circ}(c=0.1, \mathrm{MeOH}) ;$ ESI-MS $m / z: 519$ $[\mathrm{M}-\mathrm{H}]^{-}$; FAB-MS $m / z: 543[\mathrm{M}+\mathrm{Na}]^{+}$, HR-FAB-MS $m / z$ : calcd for $\mathrm{C}_{22} \mathrm{H}_{32} \mathrm{O}_{14} \mathrm{Na}$ : 543.1690. Found: 543.1725; UV $\lambda_{\max }(\mathrm{MeOH}, \mathrm{nm}): 217,235,295$ (sh), 323; $v_{\max }\left(\mathrm{KBr}, \mathrm{cm}^{-1}\right) 3372(\mathrm{OH}), 1698(\mathrm{C}=\mathrm{O}), 1635$ $(\mathrm{C}=\mathrm{C}), \quad 1600$ and 1519 (aromatic ring), 1020 (C-O-C); ${ }^{1} \mathrm{H}-\mathrm{NMR}$ (500 MHz, $\left.\mathrm{CD}_{3} \mathrm{OD}\right)$ : Table I; ${ }^{13} \mathrm{C}-\mathrm{NMR}\left(\mathrm{CD}_{3} \mathrm{OD}, 125 \mathrm{MHz}\right)$ : Table I.

Alkaline Hydrolysis of $\mathbf{1}$. Compound $\mathbf{1}(2 \mathrm{mg})$ was treated with $5 \% \mathrm{KOH}$ in $\mathrm{MeOH}$ at $80{ }^{\circ} \mathrm{C}$ for $2 \mathrm{~h}$. After neutralization with methanolic $\mathrm{HCl}(1 \%)$, the reaction mixture was evaporated to dryness. The residue was dissolved in $\mathrm{H}_{2} \mathrm{O}$ and extracted three times with $n$-BuOH. The combined $n$ - $\mathrm{BuOH}$ extracts were concentrated and compared with gentiobiose $\quad(\beta$-D-glucopyranosyl- $(1 \rightarrow 6)-\beta$-D-glucopyranoside), isomaltitol ( $\alpha$-D-glucopyranosyl- $(1 \rightarrow 6)$ glucitol) and the reduction product of gentiobiose ( $\beta$-D-glucopyranosyl- $(1 \rightarrow 6)$-glucitol $(4)$ by TLC, using two solvent systems $\left(\mathrm{CH}_{2} \mathrm{CI}_{2}-\mathrm{MeOH}-\mathrm{H}_{2} \mathrm{O}\right.$, 60:40:4 and 50:50:5) and metaperiodate (sodium)benzidine as spray reagent (Stahl, 1969).

Preparation of $\beta$-D-glycopyranosyl- $(1 \rightarrow 6)$-glucitol (4). Gentiobiose (20 mg) was dissolved in $\mathrm{H}_{2} \mathrm{O}$. 
$50 \mathrm{mg}$ of $\mathrm{NaBH}_{4}$ was added to this mixture and was kept overnight at room temperature. After neutralization with methanolic HCI (1\%), the reaction mixture was evaporated to dryness. The residue was dissolved in $\mathrm{H}_{2} \mathrm{O}$ and extracted three times with $n$-BuOH. Evaporation of the $n-\mathrm{BuOH}$ phase yielded 4.

$\beta$-D-glycopyranosyl- $(1 \rightarrow 6)$-glucitol $(4) .[\alpha]_{\mathrm{D}}^{20}-2^{\circ}$ $\left(c=0.1, \mathrm{H}_{2} \mathrm{O}\right) .{ }^{1} \mathrm{H}-\mathrm{NMR}\left(300 \mathrm{MHz}, \mathrm{D}_{2} \mathrm{O}\right) \delta: 4.53$ $(1 \mathrm{H}, \mathrm{d}, J=7.2 \mathrm{~Hz}, \mathrm{H}-1), 4.14(1 \mathrm{H}$, br d, $J=10.2$, H-6'a), 3.92 (1H, br d, $J=12.0 \mathrm{~Hz}, \mathrm{H}-6 \mathrm{a}), 3.75$ (overlapped, H-6'b), 3.70 (overlapped, H-6b), 3.853.60 (6H, overlapped, $\left.\mathrm{H}_{2}-1^{\prime}-\mathrm{H}-5^{\prime}\right), 3.50$ (overlapped, H-5), $3.49(1 \mathrm{H}, \mathrm{t}, J=9.2 \mathrm{~Hz}, \mathrm{H}-3), 3.42(1 \mathrm{H}$, $\mathrm{t}, J=9.2 \mathrm{~Hz}, \mathrm{H}-4), 3.32(1 \mathrm{H}, \mathrm{dd}, J=9.2,7.2 \mathrm{~Hz}$,

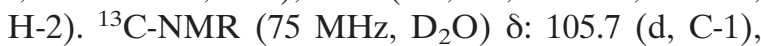
78.7 (d, C-5), 78.4 (d, C-3), 76.1 (d, C-2), 75.7 (d, C-5'), 74.2 (t, C-6'), 73.6 (d, C-4'), 72.6 (d, C-2'), 72.5 (d, C-4), $72.4\left(\mathrm{~d}, \mathrm{C}-3^{\prime}\right), 65.2\left(\mathrm{t}, \mathrm{C}-1^{\prime}\right), 63.5(\mathrm{t}$, C-6).

Reduction of DPPH radical. Methanolic solutions $(0.1 \%)$ of all isolates were chromatographed on a $\mathrm{Si}$ gel TLC plate using a $\mathrm{CHCI}_{3}-\mathrm{MeOH}-\mathrm{H}_{2} \mathrm{O}$ (61:32:7) solvent system. After drying, TLC plates were sprayed with a $0.2 \%$ DPPH (Fluka) solution in $\mathrm{MeOH}$. Compounds showing a yellow-on-purple spot were regarded as antioxidant (Cuendet et al., 1997).

\section{Results and Discussion}

The methanolic extract of the air-dried stocks of G. orientalis was fractionated by polyamide column chromatography (CC) followed by $\mathrm{C}_{18^{-}}$ MPLC and Si gel CC. Globularitol (1) was obtained as a yellowish amorphous powder. The positive- and negative ion FAB- and ESI mass spectra exhibited pseudomolecular ion peaks $[\mathrm{M}+\mathrm{Na}]^{+}$ and $[\mathrm{M}-\mathrm{H}]^{-}$at $m / z 543$ and $m / z 519$, respectively. This observation, combined with the ${ }^{1} \mathrm{H}$ - and ${ }^{13} \mathrm{C}$ NMR data (see Table I), indicated the molecular formula of $\mathrm{C}_{22} \mathrm{H}_{32} \mathrm{O}_{14}$, thus, the presence of seven degrees of unsaturation. UV absorption bands at $\lambda_{\max } 217,235,295$ (sh) and $323 \mathrm{~nm}$ indicated the phenolic nature of $\mathbf{1}$. The IR spectrum revealed absorption bands for hydroxyl $\left(3372 \mathrm{~cm}^{-1}\right), \alpha, \beta$ unsaturated ester carbonyl $\left(1698 \mathrm{~cm}^{-1}\right)$, olefinic $\left(1635 \mathrm{~cm}^{-1}\right)$, aromatic $\left(1600\right.$ and $\left.1519 \mathrm{~cm}^{-1}\right)$ and ether $\left(1020 \mathrm{~cm}^{-1}\right)$ functionalities. The ${ }^{13} \mathrm{C}-\mathrm{NMR}$ spectrum exhibited 22 distinct resonances. When
Table I. ${ }^{13} \mathrm{C}$ - and ${ }^{1} \mathrm{H}-\mathrm{NMR}\left(\mathrm{CD}_{3} \mathrm{OD}, 125 \mathrm{MHz}\right.$ for ${ }^{13} \mathrm{C}$ and $500 \mathrm{MHz}$ for ${ }^{1} \mathrm{H} \mathrm{NMR}$ ) data and HMBC correlations for $\mathbf{1}^{*}$.

\begin{tabular}{|c|c|c|c|c|}
\hline $\begin{array}{l}\mathrm{C} / \mathrm{H} \\
\text { Atom }\end{array}$ & & $\delta_{\mathrm{C}} \mathrm{ppm}$ & $\delta_{\mathrm{H}} \mathrm{ppm}, J(\mathrm{~Hz})$ & $\begin{array}{l}\mathrm{HMBC} \\
(\mathrm{H} \rightarrow \mathrm{C})\end{array}$ \\
\hline \multicolumn{5}{|c|}{ Glucose } \\
\hline 1 & $\mathrm{CH}$ & 105.0 & $4.36 \mathrm{~d}(7.8)$ & C-6' \\
\hline 2 & $\mathrm{CH}$ & 75.2 & $3.27 \mathrm{dd}(7.8,9.0)$ & $\mathrm{C}-1, \mathrm{C}-3$ \\
\hline 3 & $\mathrm{CH}$ & 77.7 & $3.39 \mathrm{t}(9.0)$ & C-4 \\
\hline 4 & $\mathrm{CH}$ & 71.7 & 3.37 t $(9.0)$ & C-3, C-6 \\
\hline 5 & $\mathrm{CH}$ & 75.6 & 3.54 ddd $(9.0,5.5,2.0)$ & C-4 \\
\hline 6 & $\mathrm{CH}_{2}$ & 64.6 & $\begin{array}{l}4.52 \mathrm{dd}(12.1,2.0) \\
4.30 \mathrm{dd}(12.1,5.5)\end{array}$ & $\begin{array}{l}\mathrm{C}-4 \\
\mathrm{C}=\mathrm{O}, \mathrm{C}-5\end{array}$ \\
\hline \multicolumn{5}{|c|}{ Glucitol } \\
\hline $1^{\prime}$ & $\mathrm{CH}_{2}$ & 65.2 & $\begin{array}{l}3.79^{\dagger} \\
3.61^{\dagger}\end{array}$ & $\begin{array}{l}\mathrm{C}-2^{\prime}, \mathrm{C}-3^{\prime} \\
\mathrm{C}-2^{\prime}, \mathrm{C}-3^{\prime}\end{array}$ \\
\hline $2^{\prime}$ & $\mathrm{CH}$ & 71.1 & $3.77^{\dagger}$ & $\mathrm{C}-1^{\prime}$ \\
\hline $3^{\prime}$ & $\mathrm{CH}$ & 70.9 & $3.76^{\dagger}$ & $\mathrm{C}-1^{\prime}$ \\
\hline $4^{\prime}$ & $\mathrm{CH}$ & 71.6 & $3.77^{\dagger}$ & \\
\hline $5^{\prime}$ & $\mathrm{CH}$ & 72.9 & $3.66^{\dagger}$ & $\mathrm{C}-3^{\prime}$ \\
\hline $6^{\prime}$ & $\mathrm{CH}_{2}$ & 73.7 & $\begin{array}{l}4.15 \mathrm{dd}(10.5,2.3) \\
3.72 \mathrm{dd}(10.5,6.3)\end{array}$ & $\mathrm{C}-1$ \\
\hline \multicolumn{5}{|c|}{$\begin{array}{l}\text { Ferulic } \\
\text { acid }\end{array}$} \\
\hline $2^{\prime \prime}$ & $\mathrm{CH}$ & 111.7 & $7.19 \mathrm{~d}(2.0)$ & C- $\beta, C-4^{\prime \prime}, C-6^{\prime \prime}$ \\
\hline $3^{\prime \prime}$ & $\mathrm{C}$ & 149.5 & & \\
\hline $4^{\prime \prime}$ & $\mathrm{C}$ & 151.0 & & \\
\hline $5^{\prime \prime}$ & $\mathrm{CH}$ & 115.1 & $6.80 \mathrm{~d}(8.2)$ & $\mathrm{C}-1^{\prime \prime}, \mathrm{C}-3^{\prime \prime}, \mathrm{C}-4^{\prime \prime}$ \\
\hline $6^{\prime \prime}$ & $\mathrm{CH}$ & 124.2 & $7.07 \mathrm{dd}(8.2,2.0)$ & $\mathrm{C}-\beta, \mathrm{C}-2^{\prime \prime}, \mathrm{C}-4^{\prime \prime}$ \\
\hline$\alpha$ & $\mathrm{CH}$ & 116.6 & $6.39 \mathrm{~d}(16.0)$ & $\mathrm{C}=\mathrm{O}, \mathrm{C}-1^{\prime \prime}$ \\
\hline$\beta$ & $\mathrm{CH}$ & 147.2 & $7.64 \mathrm{~d}(16.0)$ & $\mathrm{C}=\mathrm{O}, \mathrm{C}-2^{\prime \prime}, \mathrm{C}-6^{\prime \prime}$ \\
\hline $\mathrm{C}=\mathrm{O}$ & $\mathrm{C}$ & 169.2 & & \\
\hline $\mathrm{OCH}_{3}$ & $\mathrm{CH}_{3}$ & 56.5 & $3.89 \mathrm{~s}$ & $\mathrm{C}-3^{\prime \prime}$ \\
\hline
\end{tabular}

taken together with the ${ }^{1} \mathrm{H}-\mathrm{NMR}$, the DEPT-135 and proton-detected gHSQC spectral data, the presence of one methoxy, three methylene and fourteen methine resonances could be assigned for 1. The remaining quaternary carbons were assignable to a carbonyl ( $\delta$ 169.2) and three quaternary aromatic carbons two of which are oxygenated $(\delta$ 127.7, 149.5, 151.0). The ${ }^{1} \mathrm{H}-\mathrm{NMR}$ spectrum of $\mathbf{1}$ exhibited signals for three aromatic protons at $\delta 7.19(\mathrm{~d}, J=2.0 \mathrm{~Hz}), 7.07(\mathrm{dd}, J=2.0,8.2 \mathrm{~Hz})$ and $6.80(\mathrm{~d}, J=8.2 \mathrm{~Hz})$ as an ABX system, and two olefinic protons at $\delta 7.64$ and 6.39 as an $\mathrm{AX}$ system $\left(J_{\mathrm{AX}}=16.0 \mathrm{~Hz}\right)$. These signals, plus the methoxy singlet at $\delta 3.89$ were consistent with the presence of a trans-ferulic acid moiety. Since the feruloyl moiety accounts for six degrees of unsaturation, 1 had to have one additional ring. An an- 
omeric proton signal appeared at $\delta 4.36$ (d, H-1) and the resonances in the region of $\delta 3.27-4.52$ along with the corresponding carbon signals inferred from the gHSQC spectrum, suggested the presence of a glucopyranose unit. The $\beta$ position of the glucose was judged from the large coupling constant value $\left(J_{1,2}=7.8 \mathrm{~Hz}\right)$ of $\mathrm{H}-1$. This left six ${ }^{13} \mathrm{C}$ signals to be assigned. The DEPT-135 spectrum contained signals for two methylene and four methines in the region of $\delta 65.2-73.7$, but no anomeric carbon resonance around $\delta 100$, indicating the second sugar to be an acyclic hexitol. From this data, associated with the interpretation of the gCOSY spectrum, the hexitol was identified as glucitol (Colson et al., 1975). The gHMBC ( $J=$ $8 \mathrm{~Hz}$ ) experiment (see Table I) permitted the determination of the glycosidic linkages. The feruloyl group was positioned at C- 6 of the glucose on the basis of obvious deshielding of both $\mathrm{H}_{2}-6$ and C-6 $\left(\delta_{\mathrm{H}} 4.52 \mathrm{dd}, J=12.1,2.0 \mathrm{~Hz}, \delta_{\mathrm{H}} 4.30 \mathrm{dd}, J=12.1\right.$, $\left.5.5 \mathrm{~Hz} ; \delta_{\mathrm{C}} 64.6\right)$ and the observed long range correlations between $\mathrm{H}_{2}-6$ and the carbonyl resonance ( $\delta$ 169.2). The cross-peaks observed be- tween the anomeric proton of glucose $(\delta 4.36)$ and the $C-6^{\prime}(\delta 73.7)$ of the glucitol unit led to the identification of carbohydrate portion of $\mathbf{1}$ as $\beta$-Dglucopyranosyl-( $1 \rightarrow 6)$-glucitol. In order to confirm the proposed sugar moiety, compound $\mathbf{1}$ was subjected to alkaline hydrolysis ( $5 \%$ methanolic $\mathrm{KOH})$. The adduct was co-TLCed with gentiobiose $(\beta$-D-glucopyranosyl- $(1 \rightarrow 6)-\beta$-D-glucopyranoside), isomaltitol ( $\alpha$-D-glucopyranosyl- $(1 \rightarrow 6)$ glucitol) and $\beta$-D-glucopyranosyl- $(1 \rightarrow 6)$-glucitol (4), which was prepared by reduction of gentiobiose. The alkaline hydrolysis product of $\mathbf{1}$ gave a spot which had the same $R_{\mathrm{f}}$ value with that of $\mathbf{4}$ in two different TLC solvent systems. Furthermore, the ${ }^{1} \mathrm{H}$ - and ${ }^{13} \mathrm{C}-\mathrm{NMR}$ data of $\mathbf{4}$ were found to be identical with the carbohydrate chain of $\mathbf{1}$ (see Material and Methods). Hence, the structure of compound 1 was established as 6- $O$-feruloyl- $\beta$-Dglucopyranosyl-( $1 \rightarrow 6)$-glucitol.

Additionally, the underground parts of $G$. orientalis yielded two known sucrose esters, 6- $O$-caffeoyl- $\beta$-D-fructofuranosyl- $(2 \rightarrow 1)-\alpha$-D-gluco-

pyranoside (2) (Wang et al., 1999), 6- $O$-feruloyl- $\beta$ -
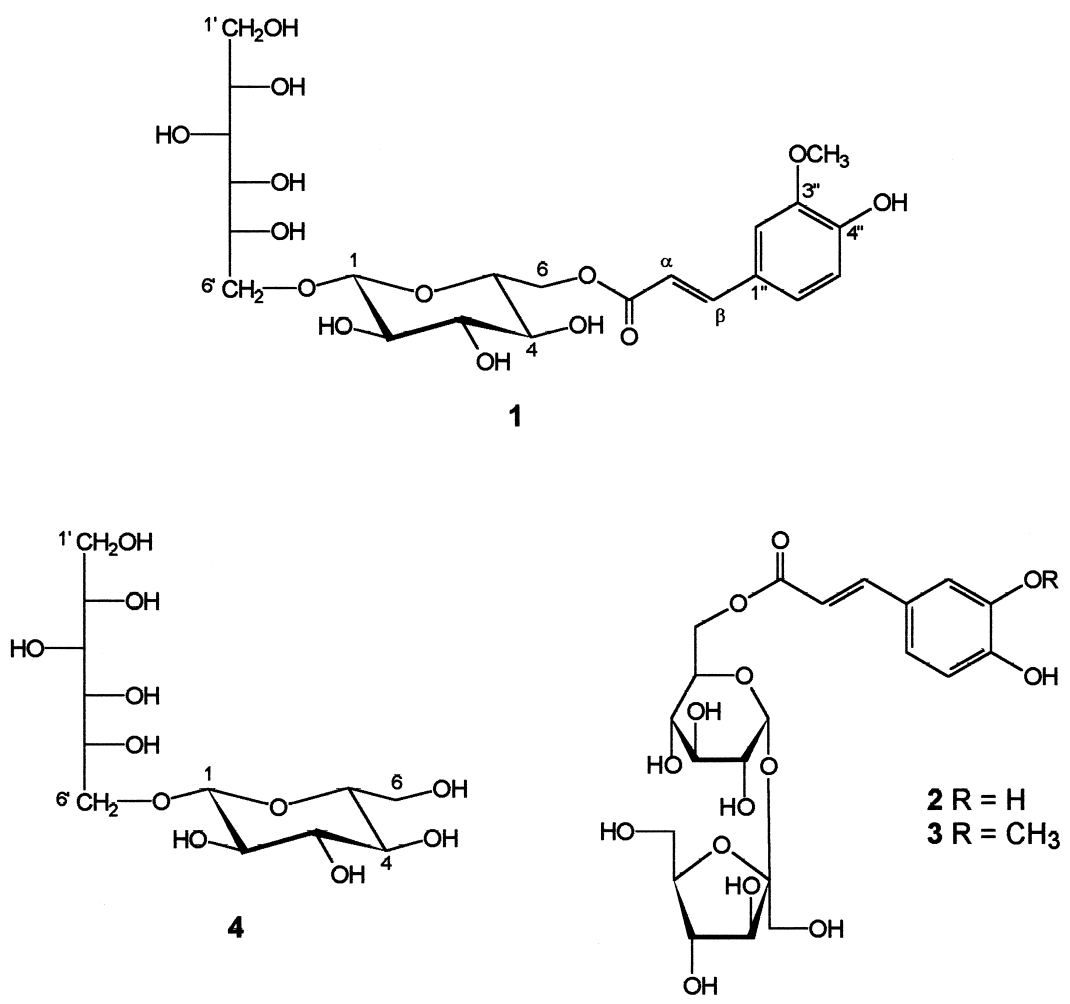

Fig. 1. Sugar esters (1-3) from G. orientalis and $\beta$-D-glucopyranosyl-(1 $\rightarrow$ 6)-glucitol (4). 
D-fructofuranosyl- $(2 \rightarrow 1)$ - $\alpha$-D-glucopyranoside $(\mathbf{3})$ (Bokern et al., 1991), 10-O-benzoylcatalpol (Foderaro et al., 1992) and geniposide (Inouye et al., 1969) were also isolated and identified by comparison of their spectral data with published values. The aerial parts of $G$. orientalis afforded an acetophenone glycoside, picein (Junior, 1984), eight iridoid glycosides; asperuloside (Otsuka et al., 1991), alpinoside (Jensen et al., 1996), aucubin (Bianco et al., 1983), catalpol (Chaudhuri and Sticher, 1981), geniposidic acid (Bianco et al., 1983; Akdemir and Calis, 1991), 10-O-benzoylcatalpol (Foderaro and Stermitz, 1992), globularin (Chaudhuri and Sticher, 1981), melampyroside (Chaudhuri and Sticher, 1980) and three phenylethanoid glycosides, calceolarioside A (Nicoletti et al., 1986), verbascoside (Sticher and Lahloub, 1982) and leucosceptoside A (Calis et al., 1988).

The antioxidant property of the isolates was tested using 2,2-diphenyl-1-picrylhydrazyl (DPPH) radical (Takao et al., 1994; Cuendet et al., 1997). Compounds 1, 2, 3, calceolarioside A, verbascoside, and leucosceptoside A showed antioxidant potential (yellow-on-purple spot) indicating their ability to efficiently scavenge free radicals. Similar sucrose esters from Polygonum lapathifolium have recently been reported to show significant inhibitory effects on the Epstein-Barr virus early antigen activation by tumor-promoters (Takasaki et al., 2001).

It is interesting that the underground parts of G. orientalis contain only simple caffeoyl sugar esters, whereas the aerial parts contain phenylethanoid glycosides which include an additional phenylethanol moiety as aglycone. However, the ability of both type of compounds to scavenge free radicals might indicate their importance for the welfare of the plant.

\section{Acknowledgments}

The authors thank Prof. Dr. Hayri Duman, Gazi University, Ankara, for authentification of the plant material. We also acknowledge Dr. Elliot Rachlin and Dr. Vajira Nanayakkara, University of Utah, for recording mass spectra.
Akdemir Z. and Calis I. (1991), Iridoid and phenylpropanoid glycosides from Pedicularis pontica Boiss. Doga - Tr. J. Pharmacy 1, 67-75.

Baytop T. (1984), Therapy with Medicinal Plants (Past and Present). Istanbul University Publications, Istanbul, No. 3255, pp. 419.

Bianco A., Passacantilli P., Polidori G., Nicoletti M. and Messana I. (1983), NMR spectroscopy of epimeric pairs of glucosidic iridoids from Rubiaceae. Gazz. Chim. Ital. 113, 829-834.

Bokern M., Heuer S., Wray V., Witte L., Macek T., Vanek T. and Strack D. (1991), Ferulic acid conjugates and betacyanins from cell cultures of Beta vulgaris. Phytochemistry 30, 3261-3265.

Calis I., Kirmizibekmez H. and Sticher O. (2001), Iridoid glycosides from Globularia trichosantha. J. Nat. Prod. 64, 60-64.

Calis I., Kirmizibekmez H., Rüegger H. and Sticher O. (1999), Phenylethanoid glycosides from Globularia trichosantha. J. Nat. Prod. 62, 1165-1168.

Calis I., Saracoglu I., Kitagawa S. and Nishibe S. (1988), Phenylpropanoid glycosides isolated from Rhynchocorys stricta (Scrophulariaceae). Doga Tu J. Med. Pharm. 12, 234-238.
Chaudhuri R. K. and Sticher O. (1980), Globularifolin, a new acyl iridoid glucoside from Globularia cordifolia. Helv. Chim. Acta 63, 117-120.

Chaudhuri R. K. and Sticher O. (1981), New iridoid glycosides and a lignan diglucoside from Globularia alypum L. Helv. Chim. Acta 64, 3-15.

Colson P., Slessor K. N., Jennings H. J. and Smith I. C. P. (1975), A carbon-13 nuclear magnetic resonance study of chlorinated and polyol analogs of glucose and related oligomers. Can. J. Chem. 53, 1030-1037.

Cuendet M., Hostettman K., Potterat O. and Dyatmiko W. (1997), Iridoid glucosides with free radical scavenging properties from Fagraea blumei. Helv. Chim. Acta 80, 1144-1152.

Davis P. H. (1982), "Flora of Turkey and East Aegean Islands," University Press: Edinburgh, Vol. 7, pp. 27-31.

Foderaro T. A. and Stermitz F. R. (1992), Iridoid glycosides from Penstemon species: A C-5, C-9 trans iridoid and C-8 epimeric pairs. Phytochemistry 31, 4191-4195.

Inouye H., Saito S., Taguchi H. and Endo T. (1969), Two new iridoglucosides gardenoside and geniposide from Gardenia jasminoide. Tetrahedron Lett. 28, 23472348. 
Jensen S. R., Olsen C. E., Rahn K.and Rasmussen J. H. (1996), Iridoid Glucosides in Plantago alpina and P. altissima. Phytochemistry 42, 1633-1636.

Junior P. (1984), Iridoidglucoside und ein acetophenonglucosid aus Penstemon whippleanus. Planta Med., 50, 444-445.

Nicoletti M., Galeffi C., Messana I., Garbarino J. A., Gambaro V., Nyandat E. and Marini-Bettola G. B. (1986), New phenylpropanoid glucosides from Calceolaria hypericina. Gazz. Chim. Ital. 116, 431-433.

Otsuka H., Yoshimura K., Yamasaki K. and Cantoria M. C. (1991), Isolation of 10-O-acyl iridoid glucosides from a Philippine medicinal plant, Oldenlandia corymbosa L. (Rubiaceae). Chem. Pharm. Bull. 39, $2049-2052$

Sezik E., Tabata M., Yesilada E., Honda G., Goto K. and Ikeshiro Y. (1991), Traditional medicine in Turkey I. Folk medicine in northeast Anatolia. J. Ethnopharm. 35, 191-196.
Stahl E. (1969), Thin-Layer Chromatography A Laboratory Handbook. Springer Publ., Berlin, Heidelberg, New York, pp. 885 .

Sticher O. and Lahloub M. F. (1982), Phenolic glycosides from Paulownia tomentosa bark. Planta Med. 46, $145-148$.

Takao T., Kitatani F., Watanabe N., Yagi A. and Sakata K. (1994), A simple screening method for antioxidants produced by marine bacteria from fish and shellfish. Biosci. Biotech. Biochem. 58, 1780-1783.

Takasaki M., Kuroki S., Kozuka M. and Konishima T. (2001), New phenylpropanoid esters of sucrose from Polygonum lapathifolium. J. Nat. Prod. 64, 1305-1308. Wang M., Shao Y., Li J., Zhu N., Rangarajan M., La Voie E. J. and Ho C-T. (1999), Antioxidative phenolic glycosides from sage (Salvia officinalis). J. Nat. Prod. 62, $454-456$. 